PRZEGLĄD RUSYCYSTYCZNY 2020, nr 3(171)

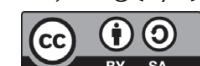

DOI $10.31261 /$ pr.7897

\title{
KRZYSZTOF TYCZKO
}

Uniwersytet im. Adama Mickiewicza w Poznaniu

(D) ORCID http://orcid.org/oooo-0oo2-8926-9641

\section{ZANIKI PAMIĘCI A LOS W DRAMACIE ASI WOŁOSZYNY ПАЦИЕНТЫ}

\section{MEMORY LOSS AND FATE IN THE ASYA VOLOSHINA'S PATIENTS}

Asya Voloshina's Patients are based on illnesses described by the British neurologist Oliver Sacks and on elements of the artistic world of the Spanish director Luis Buñuel. Combining scientific and artistic reflection, Voloshina creates his own narrative of God, freedom, fate, personality and creativity. The purpose of this article is to characterize the phenomenon of memory loss by the characters in connection with the concept of fate and in the context of the forsake by God. Memory loss means for the characters a personality loss, which entails a will loss. Thanks to the great creative effort of Masha, contributing to the creation of the last film by Ion, the release of injuries forgotten by the heroes and catharsis become possible. This conclusion is made with reference to the arguments of Nikolai Berdyaev about fate, religion and freedom (according to the book The Divine and the Human).

Keywords: theater, memory, fate, neurology, cinema

Asia Wołoszyna urodziła się w 1985 roku w Rostowie nad Donem. Dwadzieścia osiem lat później ukończyła dramaturgię w Rosyjskim Państwowym Instytucie Sztuk Scenicznych w Sankt Petersburgu. Napisała ponad dwadzieścia sztuk (włączając adaptacje literatury pięknej oraz teksty dla dzieci) - m.in. Anna Frank (Анна Франк, 2014) lub Człowiek z ryby (Человек из рыбы, 2016). Jej najnowsze sztuki to Дания тюрьма і Подтвердите, что вы человек'.

Akcja utworu Wołoszyny Пациенты toczy się w klinice dla osób cierpiących na choroby prawej półkuli mózgu. W świecie przedsta-

1 Więcej na temat twórczości Wołoszyny zob.: K. Tyczko, Wolność i tragizm, „Teatr” 2018, nr 12, s. 39-42. 
wionym działa sześć osób. Agnieszka - młoda, religijna dziewczyna, która w dzieciństwie pragnęła zostać zakonnicą, przeżyła jednak szok, gdy podczas opieki nad chorym i równie religijnym bratem dostrzegła, że ma on bluźniercze widzenie Matki Boskiej. Choroba bohaterki rozpoczęła się podczas szoku wywołanego wizją brata i polega na tym, że nie dostrzega ona prawej strony czegokolwiek - aby na przykład zjeść w całości posiłek, za każdym razem po zjedzeniu lewej połowy musi ustawić się w taki sposób, by reszta jedzenia znalazła się po jej lewej stronie. Masza - kobieta po trzydziestce, która w pewnym momencie życia utraciła zmysł kinestetyczny, musiała na nowo poznać granice swojego ciała, uczyć się go i zapamiętywać, aby móc się poruszać. Jej ruchy przypominają ruchy robota, a mowa miejscami jest nienaturalna i niepewna. Patologia Johnny'ego, starszego mężczyzny, niegdyś najprawdopodobniej nadużywającego alkoholu, polega z kolei na nieumiejętności utrzymania w pamięci wspomnień o realnych wydarzeniach (tzw. zespół Korsakowa), przy czym jego osobowość nie doznała całkowitego rozpadu - luki w pamięci wypełnia on błyskawiczną, często wysoce absurdalną konfabulacją, dzięki czemu jest w stanie w miarę normalnie spełniać podstawowe funkcje życiowe. W obejściu Johnny jest bezpośredni, nie stroni od obraźliwych epitetów pod adresem Mrs. O’Neill. Ta jest z kolei w podobnej sytuacji do Johnny'ego, z tą jednak różnicą, że amnezja nie dotyczy całego jej życia, lecz posiada cezurę - okres ślubu. Mrs. O’Neill przekonana jest o swoim młodym wieku i wciąż czeka na narzeczonego, który ma ją poprowadzić do ołtarza, a każde jej spojrzenie w lustro i kontakt z prawdziwym obliczem kończy się histerią, po chwili zaś - amnezją. Sturmberg w przeszłości był dyrektorem kliniki. Postanowił wcielić się w rolę pacjenta, by testować na sobie rozmaite preparaty. Ion to genialny reżyser, który cierpi na coraz bardziej uciążliwe zaniki pamięci. Po śmierci żony postanowił nie robić więcej filmów, gdyż wraz z jej odejściem stracił możliwość krytycznej oceny swoich pomysłów. Ostatnie swoje dni postanawia spędzić w klinice. W sztuce kilkakrotnie wspominany jest również główny lekarz, doktor Prosper, fizycznie jednak nie pojawia się ani razu w miejscu akcji. Doktor Prosper był uczniem Sturmberga i przejął po nim klinikę, gdy ten postanowił zostać pacjentem. Wołoszyna w synopsie zwraca uwagę na zamierzone znaczenie jego nieobecności, która ma wskazywać na nieobecność Boga w świecie człowieka (богооставленность). Prototypy pacjentów kliniki odnaleźć można w pracy Olivera Sack- 
sa Mężczyzna, który pomylit swoją żonę z kapeluszem (The Man Who Mistook His Wife for a Hat, 1985) oraz w filmach i pisarstwie Luisa Buñuela - Wołoszyna powołuje się w dedykacji sztuki na obu intelektualistów. Pacjenci cierpią na zaburzenia opisane przez Brytyjczyka, jednocześnie jednak historia ich życia sięga korzeniami dzieł Hiszpana. Semantyka utworu tym samym wykracza poza ramę konkretnych wydarzeń w szpitalu oraz intertekstualnych powiązań z twórczością Sacksa i Buñuela, którym została poświęcona, i staje się artystyczną realizacją pewnych ontologicznych i teologicznych idei. Tym bardziej że, jak zapewnia autorka, sztuka ta nie jest prostą opowieścią na deskach teatru o zawodowych i artystycznych dokonaniach wspomnianych twórców:

„Пациенты” - пьеса не о болезнях, не о здоровье и не о норме (и даже не о ее отсутствии). Она о том, как герои волей или не волей прячутся от себя и своей судьбы. И на этой кружной незаметной тропинке сталкиваются лоб в лоб с роком - как будто торопились на свидание с ним. При этом каждый может и сам, для себя незаметно, стать посланцем рока для кого-то другого ${ }^{2}$.

Najjaskrawszym przykładem syntetycznej metody Wołoszyny są kluczowe postaci sztuki: Agnieszka i Ion. Choroba bohaterki została opisana przez Sacksa w ósmym rozdziale Mężczyzny...: Na prawo patrz! Pani S. doznała udaru i przestała dostrzegać lewą stronę czegokolwiek: „Całkowicie utraciła pojęcie lewej strony — pisze Sacks zarówno w odniesieniu do świata, jak i do swojego własnego ciała”3. Pani S. nie była w stanie normalnie zjeść posiłku dopóki nie zaczęła korzystać z wózka inwalidzkiego, dzięki któremu, gdy pozostawała podejrzanie głodna, mogła zmienić pozycję przed talerzem tak, aby pokarm znów pojawił się w polu jej widzenia. Podobnie rzecz się miała z makijażem: pani S. malowała tylko połowę twarzy, „zostawiając lewą kompletnie nieumalowaną"4. Chcąc jej ulżyć, terapeuta ustawił kamerę tak, by transmitować lewą jej połowę na ekran, znajdujący się po jej prawej stronie. Było to jednak dla niej „niesamowite, oszałamiające, ponieważ nie czuła lewej strony swojej twarzy i ciała, którą teraz miała przed sobą na ekranie [...] - Zabierzcie to ode mnie! -

2 А. Волошина, Пацииенть, аннотация, 2015, http://www.theatre-library.ru/ authors/v/voloshina_asya (20.07.2019).

3 O. Sacks, Mężczyznā, który pomylił swoją żonę z kapeluszem, przeł. B. Lindenberg, Zysk i S-ka, Poznań 1996, s. 105.

4 Tamże. 
krzyknęła zrozpaczona" ${ }^{5}$. W przypadku Agnieszki zaś zaczerpnięty z książki Sacksa pomysł wyświetlenia prawej strony bohaterki i zrealizowania filmu o jej „poznaniu” należy do Iona, którego biografia nosi znamiona biografii Buñuela.

Warto zwrócić również uwagę na opowieść Agnieszki o genezie jej choroby. Bohaterka była jedną z pięciorga rodzeństwa. Wraz z bratem pragnęła w młodości wstąpić do klasztoru i poświęcić swoje życie Bogu, pewnego dnia jednak stała się świadkiem majaczenia chorego brata, któremu ukazała się Matka Boska. Nabożne widzenie szybko przerodziło się w realizację pożądania fizycznego, co zszokowało bohaterkę i doprowadziło w efekcie do choroby. Agnieszka pogodziła się ze swoim losem i uznała, że najwyraźniej ani ona, ani brat, nie byli godni, by stać się sługami Boga. W konstruowaniu tej postaci Wołoszyna wykorzystała historię Buñuelowskiej bogobojnej i pięknej nowicjuszki Vidiriany, która opuszcza klasztor, by opiekować się swoim wujem. Ten usypia ją i usiłuje zgwałcić, później zaś popełnia samobójstwo. Dla Vidiriany staje się to moralną przeszkodą w powrocie do klasztoru. Dziewczyna postanawia czynić dobro wśród ubogich i nauczać ich prawd wiary. Potrzebujący jednak wyszydzają jej ideały. Pod koniec filmu zawodzi się na nich także sama Viridiana. Z kolei motyw widzenia Matki Boskiej i pożądania został zaczerpnięty z filmu Droga Mleczna (La Voie Lactée, 1969) oraz ze wspomnień reżysera Moje ostatnie tchnienie (Mon dernier soupir, 1982). Jedną $\mathrm{z}$ najważniejszych bohaterek tego surrealistycznego filmu jest właśnie występująca w biblijnej linii narracyjnej Bogurodzica. Objawia się ona również dwóm heretykom w linii średniowiecznej. Maryja w filmie Buñuela została przedstawiona jako kobieta niewinna (błękitna szata), lecz ponętna (uroda, spojrzenie), dodatkowo będąca w podobnym wieku do swojego syna Jezusa, co na tle innych motywów hiszpańskiego reżysera nosi jawnie erotyczny charakter. Szczegółowy opis genezy tego zabiegu znajdujemy we wspomnieniach reżysera, w rozdziale Sny i marzenia:

Trochę później przejął mnie jeszcze mocniej inny sen. Zobaczyłem nagle Matkę Boską, całą łagodnie rozświetloną, z wyciągniętymi do mnie rękami. Jej obecność była niewątpliwa, zupełnie pewna. Mówiła do mnie, zaciekłego niedowiarka, z najwyższą czułością, pośród muzyki Schuberta, którą wyraźnie słyszałem. [...] Ukląkłem, oczy napełniły mi się łzami i nagle poczułem się ogarnięty żarliwą i niezłomną wiarą. [...] Powtarzałem jeszcze na progu przebudzenia: „Tak, tak, Najświętsza Mario Panno, wierzę!” [...]

5 Tamże, s. 107. 
Dodam, że ten sen miał charakter w pewnym sensie erotyczny. Erotyzm ten pozostawał, rozumie się samo przez się, w granicach czystej miłości platonicznej. Może gdyby sen trwał dłużej, czystość zniknęłaby, ustępując miejsca prawdziwemu pożądaniu? ${ }^{6}$

Podobnie hybrydycznym charakterem odznacza się Ion. Z jednej strony pomysł nagrania Agnieszki odsyła do przytaczanego powyżej rozdziału Mężczyzny..., z drugiej jednak Ion jest profesjonalnym reżyserem, który do ostatniego swojego filmu jako punkt wyjścia obiera ludzkie lęki. Poprzez pasję, z jaką o nich mówi („Я почувствовал много страха, и - не скрою - страх возбудил меня. Это было как мелькнувшая тень на экране. Промельк замысла, предощущение... но я не буду снимать. Человек без памяти - человек без жизни. Я без тебя"7), autorka buduje paralelę między nim i twórcą Psa andaluzyjskiego (Un Chien Andalou, 1928). Reżyser konfrontuje swoich bohaterów z ich problemami przed kamerą, co stanowi jabłko niezgody w ocenie jego działalności przez mieszkańców kliniki (w jednej z gazet Ion Bertran został określony mianem skandalisty). Postępująca amnezja zmusza go do zapisywania w notatniku swoich wspomnień. Dowiadujemy się z niego o podobieństwach biografii Bertrana do biografii Buñuela. Mam tutaj przede wszystkim na myśli historię tracących pamięć matek obu postaci oraz lęk przed utratą własnej pamięci. Ion wspomina zmarłą żonę oraz matkę, widząc w amnezji ostatniej swoją przyszłość:

Твоя смерть ускорила регрессию. Болезнь отвоёвывает каждый день новые территории моего прошлого. Нашего прошлого - вот что дерьмо. Это хорошо, что тебе не придётся увидеть, как я смотрю в твоё лицо и не узнаю. Как было с мамой. Да, я слишком хорошо знаю этот путь и все остановки на нём - особенно конечную. Она только называется конечной, а на самом деле никакого конца там нет. Там есть беспредельное топтание в толпе незнакомых лиц, которые норовят заглянуть в твоё и навязать тебе себя, сказать „как, неужели ты не помнишь...”, „ты не можешь не помнить...”. А она могла. Топтание в ожидании спасительной ночи, когда все эти приближающиеся рожи погаснут. Опаздывающей, неизвестно насколько опаздывающей ночи. Вечное недоумение... ${ }^{8}$

${ }^{6}$ L. Buñuel, Moje ostatnie tchnienie, przeł. M. Braunstein, Świat Literacki, Izabelin 2006, s. 109.

7 А. Волошина, Пациенты , 2015, http://mythos.spb.ru/?p=19 (20.07.2019), s. 7.

8 Tamże, s. 6-7. 
Dla Buñuela zaś lęk przed amnezją jest lękiem przed utratą osobowości:

Odczuwam natomiast bardzo silny niepokój, a nawet lęk, kiedy nie mogę sobie przypomnieć zdarzenia, które niedawno przeżyłem, czy też nazwiska osoby spotkanej w ciągu ostatnich miesięcy, czy nawet nazwy jakiegoś przedmiotu. Moja osobowość niespodziewanie kurczy się, rozpada. Nie mogę myśleć o niczym innym, a przecież wszystkie moje wysiłki i cała złość na nic się zdadzą. Czyżby to był początek całkowitego zniknięcia? [...] Ponad tym wszystkim zaś najgorszy z lęków: być żywym, żyć, ale nie poznawać samego siebie, nie wiedzieć, nie pamiętać, kim się jest.

Dopiero kiedy zaczynamy tracić pamięć, choćby po trochu, zdajemy sobie sprawę, że pamięć jest istotą całego naszego życia. Życie bez pamięci nie byłoby życiem, podobnie jak inteligencja bez możności wysławiania się nie byłaby inteligencją. Nasza pamięć jest naszą spójnią, naszym rozumem, naszym działaniem, naszym uczuciem. Bez niej jesteśmy niczym. ${ }^{9}$

W każdym z bohaterów Ion rozpoznaje konkretny lęk (jak już zostało powiedziane, sam reżyser również się boi, że zapomni własną żonę, a w efekcie utraci życie i osobowość): Mrs. O’Neill i Johnny żyją w permanentnej amnezji i nie są w stanie w pełni uświadomić sobie aktualnego stanu rzeczy. Bohaterka jest absolutnie przekonana o swoim młodzieńczym wieku, nieustannie czeka na narzeczonego i nie przyjmuje do wiadomości, że do ślubu nigdy nie dojdzie. Johnny z kolei reaguje przerażeniem na widok zdjętego z krzyża Chrystusa, uznając go za własnego syna, który utonął. Bohater nie jest w stanie powiązać wydarzeń w logiczną całość, a jego mózg dobudowuje konteksty do aktualnych elementów rzeczywistości bez względu na ich spójność. Sturmberg, były lekarz, boi się utracić naukową obojętność (zapomina o niej jednak wobec Agnieszki), Masza zaś, jak twierdzi, lęka się, że Bertran rzeczywiście nie zrealizuje swojego ostatniego filmu; lęk Agnieszki zaś bardzo dobrze opisał Ion w jednym ze swoich monologów:

У меня есть святая. Я хочу снять святую в аду. Да просто в бездне. Она же постоянно носит с собой пустоту. Она её даже не чувствует, но она про неё знает. Увидеть её - о-о-о! Что такое пустота? А? Я отвечу. Я хорошо знаю, чего она боится. Кажется, мне это даже приснилось. Она боится увидеть отсутствие Бога. Отсутствие Бога. Доказательство его отсутствия. Пустота. Я сниму это. Мне казалось, что это главное, что я сниму в жизни. Святую, обреченную на муку, святую, смотрящую в бездну своего страха. Как тебе? Что ты думаешь? Не спи, не спи. Ничего не выходит. Пустота. Ничего я больше не вижу твоими глазами ${ }^{10}$.

9 L. Buñuel, Moje..., s. 8-9.

${ }^{10}$ А. Волошина, Пацииенты ..., s. 35. 
Świat przedstawiony sztuki z jednej strony określony jest przez lęki, z drugiej zaś naznaczony jest nieobecnością lekarza Prospera, będącą symbolem nieobecności Boga w świecie człowieka. Zgodnie ze słownikiem terminów prawosławnych słowo богооставленность posiada trzy podstawowe znaczenia:

1) утрата человеком Божественной благодати; 2) скорбное чувство, испытанное Господом Иисусом Христом (по человеческому естеству) на Кресте, в соответствии с Божьим Промыслом (Мф.27:46); 3) кажущееся отступление Бога от человека или общества людей (племени, народа и т. п.), проявляющееся в формальном ослабевании Божественной поддержки (Суд.6:13) ${ }^{11}$.

Dla niniejszego wywodu szczególnie istotne są drugie i trzecie znaczenia bogoostawlennosti: tzw. ciemna noc, której doświadczył Chrystus-człowiek na krzyżu oraz samotność człowieka wobec poczucia nieobecności Boga i braku jego pomocy. Dla wszystkich znaczeń charakterystyczne jest wrażenie utraty łączności z transcendencją, a więc niemożność intelektualno-duchowego przekroczenia ram czasoprzestrzennych i podatność na działanie sił immanentnych.

Temat bogoostawlennosti podejmuje w Egzystencjalnej dialektyce Boga i człowieka Nikołaj Bierdiajew. Dla filozofa ma ona status tajemnicy i stoi w sprzeczności z tradycyjną nauką o Opatrzności, posiadającą racjonalistyczne podłoże. Bogoostawlennost' dotyczy nie tylko porzucenia Boga przez człowieka, lecz w pierwszej kolejności odejścia człowieka od Boga. Wówczas plan wydarzeń jest moderowany przez fatum, natomiast, jak pisze Bierdiajew,

człowiek i świat poddają się nieodwracalnej konieczności w wyniku fałszywie ukierunkowanej wolności. [...] przypadek, grający ogromną rolę w życiu, jest jakby zatraceniem się i brakiem pomocy w świecie wielorakim, w którym działa ogromna ilość sił niepoddających się racjonalnemu zbadaniu. Nieszczęśliwy wypadek, który wydaje się całkowicie bezsensownym i okrutnym, oznacza, że żyjemy w świecie upadłym, w którym Bóg nie rządzi całością. Jednak ten nieszczęśliwy przypadek może otrzymać wyższy sens w moim losie, rzuconym w świat fenomenów ${ }^{12}$.

Stan bogoostawlennosti jest zdaniem filozofa m.in. efektem narzucenia Bogu kategorii i wyobrażeń charakterystycznych dla wtór-

${ }^{11}$ Азбука веры, 2005, https://azbyka.ru/bogoostavlennost (20.07.2019).

${ }^{12}$ Por. M. Bierdiajew, Egzystencjalna dialektyka Boga i człowieka, przeł. H. Paprocki, Wydawnictwo Antyk, Kęty 2004, s. 14. 
nego świata materialnego, co doprowadziło do uznania ludzkich narracji za część Objawienia (tutaj Bierdiajew lokuje zgodę na uznanie lęku przed Bogiem jako racjonalnym sędzią za stan pożądany do rozwoju moralności i duchowości). Charakterystyczne jest w tym kontekście paniczne odżegnywanie się Agnieszki od wszystkiego, co choć odrobinę może naruszyć wyobrażany przez nią ideał absolutnej niewinności i cnoty. Słowa o pustce, która nieustannie towarzyszy bohaterce, można rozumieć jako obnażenie jej przywiązania do stanu nieskalania, podczas gdy rzeczywisty stan jej religijności i wolności oznacza sprzężenie z paniką i strachem. W kontekście rozważań Bierdiajewa Agnieszka stoi po stronie religijności niewolniczej, gdzie człowiek nie jest potrzebny Bogu, lecz stanowi dodatek pomnażający jego chwałę ${ }^{13}$. Bertran w tym sensie poddaje jej wiarę próbie, podobnie do bluźnierstw, przez które musiała przejść Viridiana. Tradycyjna nauka o Opatrzności, zdaniem rosyjskiego filozofa, paradoksalnie

doprowadziła do ateizmu, gdyż sprawiła, że teodycea stała się niemożliwą. Bóg objawia się światu i człowiekowi, objawia się w Duchu ale nie rządzi światem w tym sensie, w jakim świat rozumie rządzenie. [...] Fałszywa nauka o Opatrzności prowadziła do niewolniczego uznania siły i władzy, do apoteozy sukcesu w tym świecie i ostatecznie do usprawiedliwienia zła ${ }^{14}$,

a to z kolei oznacza partykularyzację Sensu i uznanie sił wyższych, które rządzą człowiekiem jako częścią przyrody, za fatalne.

Zupełnie inne jest podejście Maszy (Marija) do choroby i otaczającej ją rzeczywistości - Rosjanka prowadzi Bertrana ku zrealizowaniu idei filmu i jako jedyna nadaje swojemu cierpieniu głębszy, przekraczający własną utratę sens, przy czym bohaterka zdaje sobie sprawę z jej rozmiarów:

Так уж вышло, что я потеряла и свою жизнь и своё тело. Но так уж вышло, что у меня появились некоторые надежды. На то, что моя жизнь начнёт быть не такой уж бессмысленной, благодаря самой болезни, которая, собственно, и отняла у меня жизнь. Я непонятно сейчас сказала? Я имею в виду, что я совсем не какой-нибудь особенный человек. Скорей всего, у меня даже не было бы шанса хоть раз посидеть с таким известным парнем, как вы. Но сейчас... как вы там говорили о пути? Сейчас у меня вдруг появилась маленькая возможность поучаствовать в некотором и правда важном. В некотором выходящем из обычного ряда. В некотором... как это говориться? великом ${ }^{15}$.

${ }_{13}$ Por. tamże, s. 13.

14 Tamże.

15 А. Волошина, Пацииенты ..., s. 15. 
Wraz z utratą dotychczasowych możliwości Masza upatruje w swojej chorobie otwarcie nowych i wykazuje przede wszystkim troskę o sukces pracy Bertrana, ofiarnie mu w tym pomagając, pozostając $\mathrm{w}$ tle i nie żądając nic w zamian.

Pamięć dla bohaterów sztuki i ich prototypów jest synonimem osobowości, utrata pamięci zaś powoduje utratę dostępu do życia, a więc również do twórczej woli (zatarciu ulegają związki przyczynowo-skutkowe). Wołoszyna opisała rzeczywistość, w której człowiek zostaje wyrwany z kontekstu zadomowienia i łączności ze światem i jego Stwórcą, co paradoksalnie prowadzi do utraty samodzielności (klinika). Szok doznany dzięki filmowi Iona daje pewną możliwość powrotu do własnej historii: pacjenci zaczynają mówić w swoich rodzimych językach i przypominają sobie to, co pozostawało dla nich zakryte. Los może być wówczas rozumiany nie tyle jako fatum, które popycha człowieka ku degradacji, ile jako pewien kompleks czynników, stanowiący o kształcie jednostki, aksjologicznie neutralny, do którego dostęp jako do partykularnej prawdy może mieć wyzwalający wpływ.

\section{REFERENCES}

Azbuka very, 2005, https://azbyka.ru/bogoostavlennost [Азбука веры, 2005, $<$ https://azbyka.ru/bogoostavlennost>].

Bierdiajew, Mikołaj. Egzystencjalna dialektyka Boga i czlowieka. Transl. Paprocki, Henryk. Kęty: Wydawnictwo Antyk 2004.

Buñuel, Luis. Moje ostatnie tchnienie. Transl. Braunstein, Maria. Izabelin: Świat Literacki 2006.

Sacks, Oliver. Mężczyzna, który pomylit swoja żonę z kapeluszem. Transl. Lindenberg, Barbara. Poznań: Zysk i S-ka 1996, s. 105.

Tyczko, Krzysztof. "Wolność i tragizm." Teatr 2018, no. 12, 39-42.

Voloshina, Asya. Patsiyenty, annotatsiya. 2015, http://www.theatre-library.ru/ authors/v/voloshina_asya [Волошина, Ася. Пациенты, аннотация. 2015, $<$ http://www.theatre-library.ru/authors/v/voloshina_asya $>$ ].

Voloshina, Asya. Patsiyenty, 2015, http://mythos.spb.ru/?p=19 [Волошина, Ася. Пациенты, 2015, <http://mythos.spb.ru/?p=19>]. 